\title{
DAVID WEITZMAN
}

David Weitzman, cardiologist to St. Bartholomew's Hospital for only three years, died on August 3,1964 , aged 45 years.

He was born on November 1, 1918, and educated at Hackney Downs Grammar School. He qualified from Bart's in 1942 and showed his ability by obtaining the M.R.C.P. a year later. He then served in the R.A.M.C. from 1943 to 1946, first as medical officer to the Buffs where he took part in the Anzio landings and was mentioned in despatches; and later as a graded physician at the British Military Hospital at Graz. His time abroad was also employed in learning Italian which he spoke fluently and utilized subsequently for translating and abstracting from Italian journals. His infective good spirits proved of value to the troops' morale in tight corners.

On his return to London he spent four years at St. Stephen's Hospital, Chelsea, where he consolidated his experience in general medicine and obtained the London M.D. In 1952 he was appointed registrar to the National Heart Hospital and subsequently became senior registrar. His training in cardiology was rapidly achieved owing to his intense interest in the subject and he was soon teaching others. His clear basic approach to any subject made him a most popular teacher with the postgraduate students. His clinical ability, his patience, and kindness likewise endeared him to patients and to colleagues. His good humour and philosophical approach to instrumental or human shortcomings made him equally popular with technicians and nursing staff. In addition to these attributes he had an alert, critical, and inquiring mind that led him into several fields of research. He worked initially on phonocardiography and published several papers from these studies. He simplified blood quinidine estimations by the development of a technique for urine assay.

From 1954 to 1961 he held successive posts at Bart's as medical tutor and casualty physician. He rapidly established a reputation as an undergraduate teacher and his courses at Bethnal Green were always well attended. Although these appointments were in general medicine he pursued his cardiological interests as a research assistant in the department at Bart's and held a clinical assistantship to Graham Hayward at the National Heart Hospital. He studied coronary heart disease from the clinical, cardiographic, and biochemical aspects in a series of patients followed for several years. Following a trip to Bethesda he introduced radio-krypton for the detection of intracardiac shunts. The breadth of his scope as a teacher together with his concise clarity are well illustrated in his two excellent books, Principles of Medicine for Nurses and Synopsis of Cardiology.

His appointment as consultant cardiologist to Bart's in 1961 satisfied his professional ambition but led to even longer hours of work. His conscientiousness to his patients led to a great demand on his time from practitioners, but in addition to this, and the time he devoted to research, David Weitzman had many other interests-opera, the ballet, and especially horse racing. More recently they had included modern painting and he had started a collection. Also he was a voracious reader and was always several books ahead of his friends. His natural charm was most evident when he relaxed with a few friends over a good dinner. Conversation was usually led by David and his quiet wit, never malicious, was paralleled only by his skill as a raconteur. Horse racing was always a great interest, and at one time he devoted several evenings a week to the scientific study of "form". Week-ends were usually spent at race meetings of the smaller sort where a thorough knowledge of the course, the weather, and each horse's previous history could be used to forecast the outcome. Meetings such as the "National" where chance played a greater part interested him far less. 


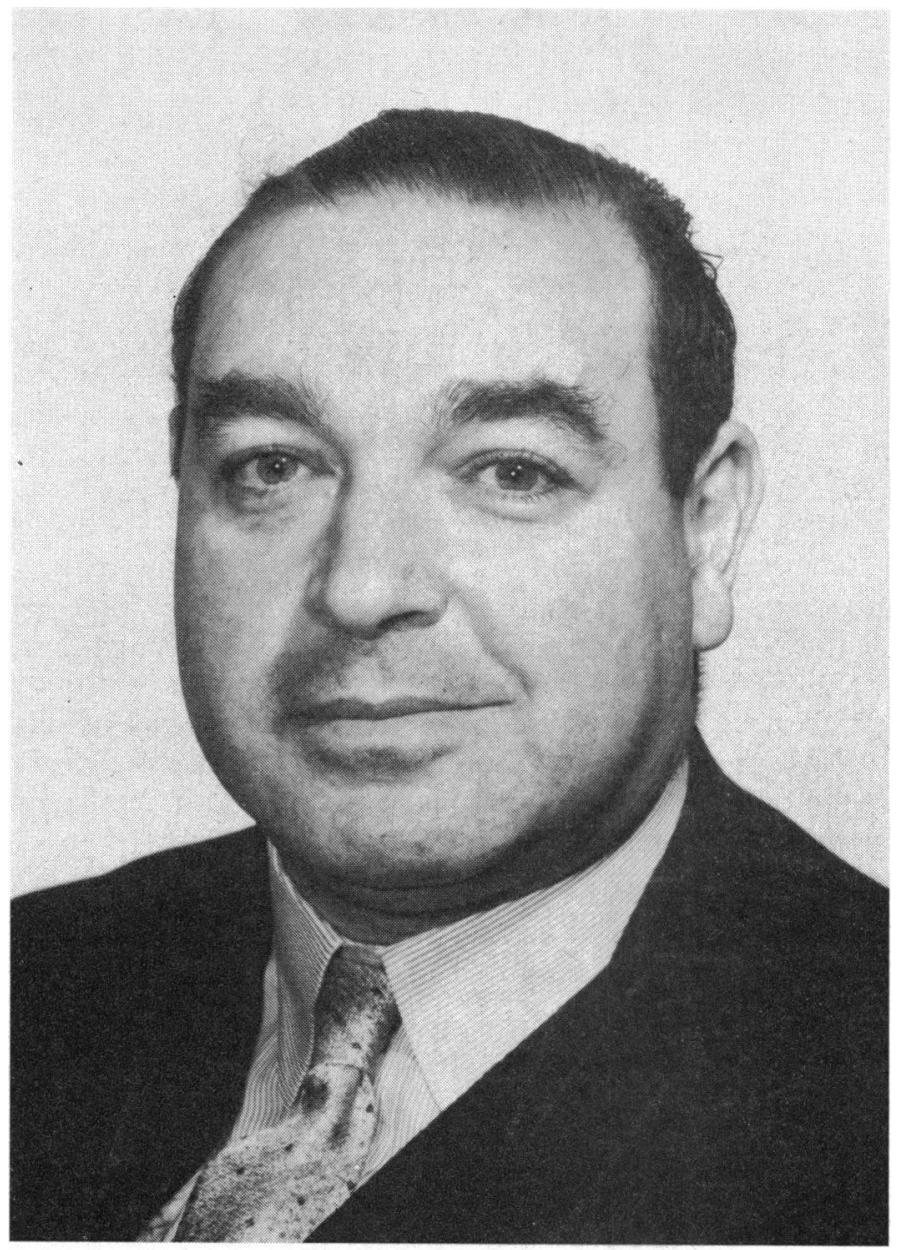

DAVID WEITZMAN

His private life was clouded by two misfortunes which he met with the greatest courage. His young wife Sylvia died in 1961 after a prolonged illness. He himself, though he looked so robust, suffered from high blood pressure for many years. He never allowed this to interfere with his work. Nor would he permit his friends to be troubled by his worries or his illness. Even after his initial infarct he returned prematurely to work and was determined to avoid any hint of invalidism.

He was elected F.R.C.P., London, in July 1964, and was admitted to the Fellowship less than a week before his death. He had partially recovered from his second infarct by this time and had resumed part-time work. His death occurred suddenly after dinner following a day at the Epsom races. He would have wished for no better way. He left no family, but many students, colleagues, patients, and friends will miss him greatly.

EDWIN BESTERMAN 